\title{
Paecilomyces niveus Stolk \& Samson, 1971 (Ascomycota: Thermoascaceae) as a pathogen of Nasonovia ribisnigri (Mosley, 1841) (Hemiptera, Aphididae) in Brazil
}

\author{
M. A. C. Zawadneak ${ }^{a *}$, I. C. Pimentel ${ }^{b}$, D. Robl ${ }^{b}$, P. Dalzoto ${ }^{b}$, V. Vicente ${ }^{b}$, D. R. Sosa-Gómez ${ }^{c}$, \\ M. Porsani ${ }^{b}$ and F. L. Cuquel
}

${ }^{a}$ Laboratório de Entomologia Prof. Ângelo Moreira da Costa Lima, Departamento de Patologia Básica, Universidade Federal do Paraná - UFPR, CP 19020, CEP 81531-980, Curitiba, PR, Brazil

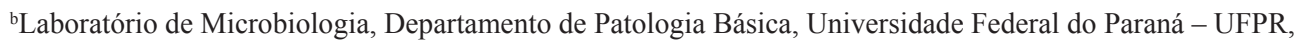
CP 19020, CEP 81531-980, Curitiba, PR, Brazil

'Laboratório de Entomologia, Embrapa Soja, CP 231, CEP 86001-970, Londrina, PR, Brazil

${ }^{d}$ Departamento de Fitotecnia e Fitossanitarismo, Universidade Federal do Paraná - UFPR, Rua dos Funcionários, CP 1540, CEP 80035-050, Curitiba, PR, Brazil

*e-mail: mazawa@ufpr.br

Received: May 2, 2014 - Accepted: August 27, 2014 - Distributed: November 30, 2015

(With 2 figures)

\begin{abstract}
Nasonovia ribisnigri is a key pest of lettuce (Lactuca sativa L.) in Brazil that requires alternative control methods to synthetic pesticides. We report, for the first time, the occurrence of Paecilomyces niveus as an entomopathogen of the aphid Nasonovia ribisnigri in Pinhais, Paraná, Brazil. Samples of mummified aphids were collected from lettuce crops. The fungus $P$. niveus (PaePR) was isolated from the insect bodies and identified by macro and micromorphology. The species was confirmed by sequencing Internal Transcribed Spacer (ITS) rDNA. We obtained a sequence of $528 \mathrm{bp}$ (accession number HQ441751), which aligned with Byssochlamys nivea strains (100\% identities). In a bioassay, $120 \mathrm{~h}$ after inoculation of $N$. ribisnigri with pathogenic $P$. niveus had an average mortality of $74 \%$. The presence of $P$. niveus as a natural pathogen of $N$. ribisnigri in Brazil suggests that it may be possible to employ $P$. niveus to minimize the use of chemical insecticides.
\end{abstract}

Keywords: Lactuca sativa, Aphididae, entomopathogenic fungi, biological control.

\section{Registro de Paecilomyces niveus Stolk \& Samson, 1971 (Ascomycota: Thermoascaceae) como patógeno de Nasonovia ribisnigri (Mosley, 1841) (Hemiptera, Aphididae) no Brasil}

\begin{abstract}
Resumo
Nasonovia ribisnigri é uma praga-chave do cultivo de alface (Lactuca sativa L.), exigindo métodos alternativos ao controle químico. Este trabalho registrou pela primeira vez, a ocorrência de Paecilomyces niveus como agente entomopatogenico do afídeo N. ribisnigri em Pinhais, Paraná, Brasil. Amostras de afídeos mumificados foram coletadas em plantas de alface. O fungo P. niveus (PaePR) foi isolado do corpo dos insetos e identificado por macro e micromorfologia e, confirmado por sequenciamento da região ITS do DNA ribossomal. A sequencia parcial de 528 bp (número de acesso HQ441751) apresentou alinhamento com 100\% de identidade com sequencias de raças de Byssochlamys nivea. No bioensaio de patogenicidade $P$. niveus apresentou uma mortalidade média de $N$. ribisnigri de $74 \%$ até 120 horas da inoculação. O registro da presença de $P$. niveus como um patógeno natural de $N$. ribisnigri no Brasil sugere o potencial de utilização para minimizar o uso de inseticidas.
\end{abstract}

Palavras-chave: Lactuca sativa, Aphididae, fungo entomopatogênico, controle biológico.

\section{Introduction}

Aphids (Hemiptera: Aphididae) are key pests of lettuce (Lactuca sativa L.) (Díaz et al., 2010). Nasonovia ribisnigri (Mosley) is one of the most important aphid parasites of lettuce (Reinink and Dieleman, 1993; Asman, 2007). $N$. ribisnigri is found throughout the lettuce head, even in the developing leaves at the center, whereas other 
species prefer external leaves (Liu and McCreight, 2006; Scorsetti et al., 2010). Chemical pesticides are the primary means of aphid control (Barber et al., 1999; Dedryver et al., 2010). However, N. ribisnigri is resistant to some insecticides (Martin et al., 1996; Rufingier et al., 1997; Barber et al., 1999; Dedryver et al., 2010). One alternative to the use of insecticides to reduce the occurrence of this pest is integrated pest management involving the application of entomopathogenic fungi (Dorschner et al., 1991; Zaki, 1998; Steinkraus, 2006; Asman, 2007; Díaz et al., 2010; Scorsetti et al., 2010, 2012; Skinner et al., 2012). Fungal pathogens are the most important pathogens of aphids and epizootics are frequently observed that often rapidly reduce aphid populations (Steinkraus, 2006). Chemical insecticides and biological control by entomopathogenic fungi may be used alternatingly or simultaneously, if compatibility or synergism between them is identified (Anhalt et al., 2010).

Several Ascomycota genera, such as Beauveria, Lecanicillium and Isaria also infect aphids (Humber et al., 2011). There is very little available information about the control of aphids using entomopathogenic fungi in Brazil. New fungal strains are important for $N$. ribisnigri control, and may lead to improvements in lettuce production.

We report, for the first time, the occurrence of $P$. niveus as entomopathogen of the aphid $N$. ribisnigri in Pinhais, Paraná, Brazil.

\section{Material and Methods}

\subsection{Collection, isolation, and identification of filamentous fungi}

During the monitoring of the entomofauna in a commercial lettuce crop in Pinhais Country, Paraná,

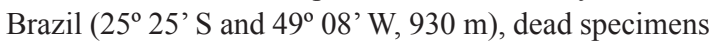
of $N$. ribisnigri with fungal mycelia growth on the body surface were found. The climate in the area was temperate according to Köppen as Cfb, (Peel et al., 2007), the average temperature was $21.2 \pm 5^{\circ} \mathrm{C}$, and the relative humidity was $84 \pm 10 \%$.

Twenty mummified aphid specimens were collected during the fall. To promote fungal development and sporulation and to confirm that fungal infection was the cause of aphid death, specimens were placed on moist filter paper inside plastic Petri dishes, and then incubated for 7 days at $25 \pm 1{ }^{\circ} \mathrm{C}$ under a 16:8 h light:dark photoperiod, and $60 \pm 10 \%$ relative humidity $(\mathrm{RH})$ Fungal mycelia grown on the surface of insect bodies and cultured for 7 days on potato dextrose agar medium (PDA) at $28^{\circ} \mathrm{C} \pm 1{ }^{\circ} \mathrm{C}$.

Preliminary fungal identification was carried out by examining the macro and microscopic features of the colonies after slide culturing on PDA at $28 \pm 1{ }^{\circ} \mathrm{C}$ (Hoog and Guarro, 2000).

Molecular identification of the fungus was performed by sequencing internal transcribed spacer (ITS) rDNA. Purified DNA was obtained as described in Gerrits van den Ende and Hoog (1999). The rDNA regions ITS1,
$58 \mathrm{~S}$, and ITS2 were sequenced using ITS5 and ITS4 primers (White Junior et al., 1990). Sequencing was performed in an automated sequencer (ABI 3700, Applied biosystems, Foster City, CA, USA). Sequences were edited and aligned using the Staden sequence analysis package v1.6.0 (Staden, 1996). Sequence analysis was performed using the sequence alignment software BLASTn, which was run against the NCBI's database (National Center for Biotechnology Information website).

Phylogenetic analysis was performed using Mega 5.1 software (Tamura et al., 2007) and applying the neighbor-joining method (Saitou and Nei, 1987), and Jukes-Cantor correct distance model (Jukes and Cantor, 1969).

\subsection{Pathogenicity bioassays}

Koch's postulates were used to determine the link between $P$. niveus and $N$. ribisnigri. In order to produce an inoculum, a suspension of the isolate was grown on PDA for 7 days at $28{ }^{\circ} \mathrm{C} \pm 1{ }^{\circ} \mathrm{C}$ in Petri dishes and then incubated for an additional seven days at $25^{\circ} \mathrm{C} \pm 1{ }^{\circ} \mathrm{C}$, a 16:8 h light:dark photoperiod under $70 \pm 10 \% \mathrm{RH}$. The concentration of conidia in the filtrate was estimated using an improved Neubauer brightline hemocytometer (Reichart) under a Leitz Dialux 20 EB light microscope (400x). Suspensions were diluted to a final concentration of $1 \times 10^{8}$ conidia $\mathrm{mL}^{-1}$.

A total of 100 third-instar $N$. ribisnigri nymphs were randomly assigned to a fungal treatment group and untreated control group. For each treatment, a 50-mm diameter leaf disc was cut out of a healthy lettuce plant. For the fungal treatment group, the leaf disc was dipped with $2 \mu \mathrm{L}$ of conidial suspension using a micropipette. The leaf discs were then fed to aphids in Petri dishes containing filter paper moistened with sterile distilled water. Each dish contained 10 aphids. The aphids were then transferred to an environmentally controlled room $\left(25 \pm 1{ }^{\circ} \mathrm{C}, 16: 8 \mathrm{~h}\right.$ light: dark photoperiod with $70 \pm 10 \% \mathrm{RH}$ ) and evaluated every 2 days for 10 days. Dead insects were collected and immersed in $70 \%$ ethanol for surface sterilization and were then transferred to individual Petri dishes containing moist filter paper and incubated for 7 days at $25 \pm 1{ }^{\circ} \mathrm{C}$ under a 16:8 h light:dark photoperiod and $60 \pm 10 \% \mathrm{RH}$.

\subsection{Statistical analysis}

Mortality data were corrected using the Abbott Formula (Abbott, 1925) and percentage values were arcsine transformed $(\sqrt{ }(\mathrm{x} / 100))$. Mean mortality data (fungus and water) were compared using the Scott-Knott test as implemented in Sisvar 5.3 software (Ferreira, 2010). Results were considered significant at the 0.05 level.

\section{Results}

Paecilomyces niveus (PaePR) was the only fungus recovered from $N$. ribisnigri collected from lettuce. After sequencing the PCR amplicon of the ITS regions of the fungal rDNA we obtain a sequence of $528 \mathrm{bp}$ (Table 1). 
Table 1. Fungal strains used for phylogenetic analysis of Paecilomyces niveus isolated from the aphid Nasonovia ribisnigri.

\begin{tabular}{|c|c|c|c|c|}
\hline Name & Gene Bank & Source & Origin & $\begin{array}{c}\text { Size } \\
\text { sequence (bp) }\end{array}$ \\
\hline Paecilomyces niveus & HQ441751 & Nasonovia ribisnigri & Brazil & 528 \\
\hline Byssochlamys nivea & FJ389938 & Oat grain & Ukraine & 569 \\
\hline Byssochlamys nivea & FJ389936 & Pasteurized fruit juice & Switzerland & 566 \\
\hline Byssochlamys nivea & FJ389935 & Milk of cow & USA & 566 \\
\hline Byssochlamys nivea & DQ464363 & $\begin{array}{c}\text { Surface of mechanical grape } \\
\text { harvester }\end{array}$ & USA & 536 \\
\hline Byssochlamys nivea & FJ389936 & Pasteurized fruit juice & Switzerland & 569 \\
\hline Byssochlamys fulva & FJ389943 & Fruit juice & Switzerland & 569 \\
\hline Byssochlamys fulva & FJ389940.1 & Bottled fruit & UK & 566 \\
\hline Byssochlamys fulva & FJ389941 & Unknown source & - & 566 \\
\hline Byssochlamys fulva & DQ459372 & Vineyard soil & - & 547 \\
\hline Paecilomyces saturatus & FJ389951 & Acetic acid & Brazil & 567 \\
\hline Byssochlamys lagunculariae & FJ389946 & Unknown source & France & 567 \\
\hline Byssochlamys lagunculariae & FJ389945 & Pasteurized strawberries & Netherlands & 567 \\
\hline Paecilomyces saturatus & FJ389950 & Unknown source & Japan & 568 \\
\hline Paecilomyces formosus & FJ389920 & Annona squamosa & Brazil & 569 \\
\hline Paecilomyces formosus & FJ389921 & Soil & Thailand & 570 \\
\hline Paecilomyces variotii & FJ895878 & Soil & Brazil & 610 \\
\hline Paecilomyces variotii & AY753331 & Soil & Thailand & 551 \\
\hline Byssochlamys zollerniae & FJ389933 & $\begin{array}{l}\text { Wood of Zollernia ilicifolia } \\
\text { and Protium heptaphyllum }\end{array}$ & Brazil & 564 \\
\hline Paecilomyces sinensis & EU272527. & Espeletia sp. & Colombia & 627 \\
\hline Paecilomyces divaricatus & FJ389932. & Pectin & Mexico & 560 \\
\hline
\end{tabular}

Comparison of the obtained sequence to others in the database suggested that the isolate was from Byssochlamys nivea (FJ389938 with $100 \%$ of similarity), which is the teleomorphic phase of Paecilomyces niveus. The obtained sequence had $94-100 \%$ similarity to sequences from 21 strains of Paecilomyces sp., and these were used for phylogenetic analysis (Figure 1). The sequence was aligned and submitted to Genbank (accession number HQ441751).

A tree based on rDNA ITS sequencing was built using a neighbor-joining method and applying Jukes-Cantor correct distance model with 1000 bootstrap inferences, as implemented in Mega 4.0.2. Two major groups with high bootstrap values were obtained. The isolate PaePR was clustered with its teleomorph, $B$. nivea.

Pathogenicity assays showed significant difference between two treatments $(\mathrm{F}$-value $=110.162 \mathrm{p}$-value $<0.001)$. $N$. ribisnigri showed a mean mortality of $74 \% 120$ hours after inoculation with $P$. niveus. Control aphids remained asymptomatic and had a mortality of $12 \%$. The pathogen was recovered from the insect body surface and the identitity of the pathogen was confirmed as $P$. niveus using morphological and molecular techniques (Figure 2).

The isolate PaePR is deposited in the Mycological Collection LabMicro- Laboratório de Microbiologia e Biologia Molecular, Departamento de Patologia Básica, Setor de Ciências Biológicas, Universidade Federal do Paraná, Curitiba, PR, Brazil.

\section{Discussion}

The genus Paecilomyces is a mitosporic fungus that has a wide natural distribution and several entomopathogenic species (Alves, 1998; Steinkraus, 2006; Zimmermann, 2008; Sun and Liu, 2008). Although this entomopathogen infects several pests (Alves, 1998), this is the first record of its attack on $N$. ribisnigri. Hypocreales (Ascomycota) can be important for reducing aphid populations (Steinkraus, 2006).

According to Samson et al. (2009) the genus Byssochlamys is morphologically well defined and characterized by almost naked ascomata in which croziers and globose asci are formed with ellipsoidal ascospores. All Byssochlamys species have a Paecilomyces anamorph that belongs to the Paecilomyces sect.

The isolate was initially characterized as Paecilomyces sp. by macro- and micro-morphological analysis. ITS sequencing and phylogenetic analysis indicated that the isolate (PaePR) obtained in this study was clustered with its teleomorph, B. nivea. Samson et al. (2009) verified by phylogenetic analyses that the genus Byssochlamys includes nine species, five of which form teleomorphs, i.e., B. fulva, B. lagunculariae, B. nivea, B. spectabilis and $B$. zollerniae, whereas four are asexual, namely P. brunneolus, $P$. divaricatus, P. formosus, and P. saturatus.

This is the first report of $P$. niveus as a parasite of N. ribisnigri in Brazil. This study provides data for future research into the use of fungal isolates for the 


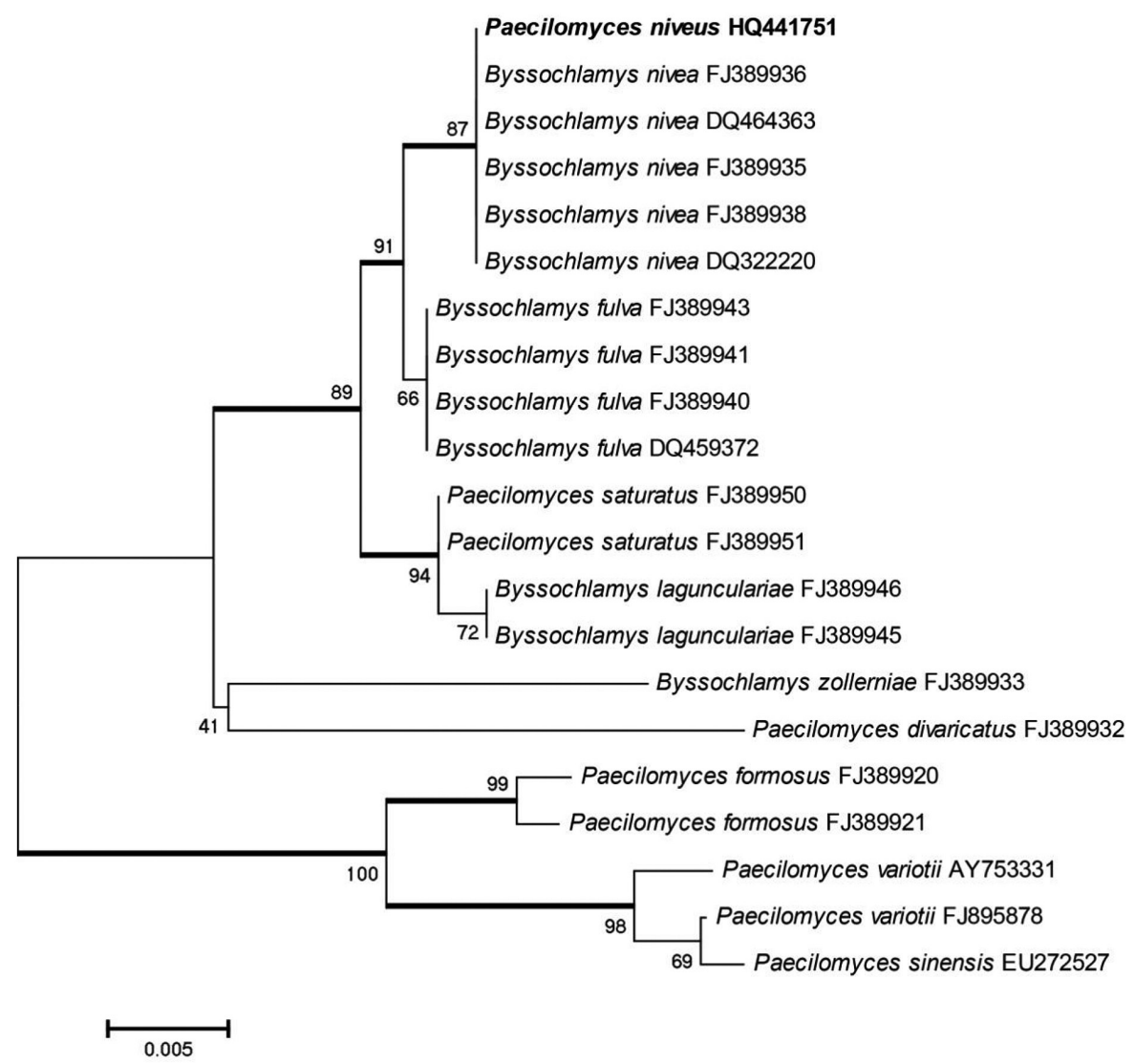

Figure 1. Phylogenetic tree of Paecilomyces and Byssochlamys species based on ITS sequences. The tree was constructed using a neighbor-joining method, as implemented in MEGA 4.0.2. Bold branches indicate bootstrap values $>80$ from 100 resampled datasets. The strain in bold, Paecilomyces niveus, was isolated as part of this study. The sequence for this strain is available in GenBank, accession No. HQ441751.
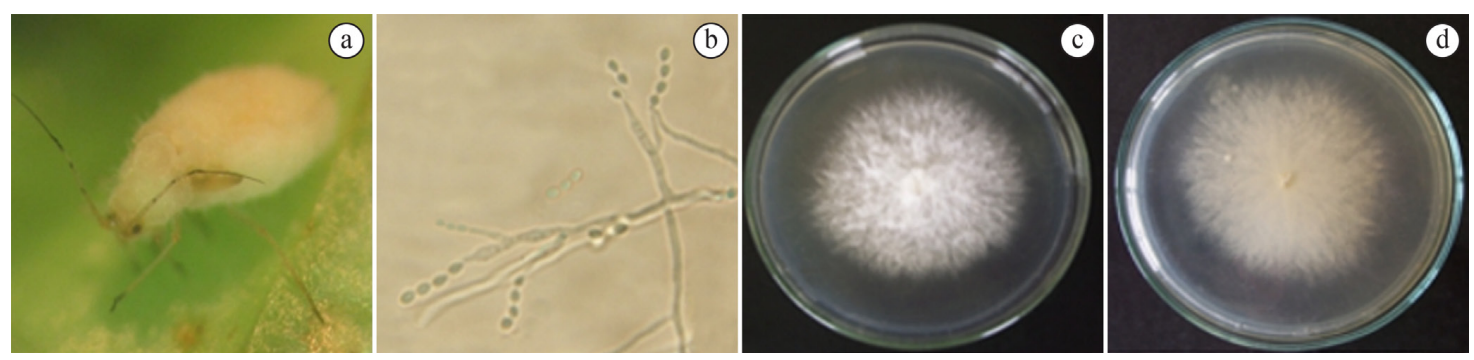

Figure 2. Nasonovia ribisnigri body covered by Paecilomyces niveus mycelia (a); Micromorphology of $P$. niveus mycelia using optical microscopy (40X) showing conidiophores and conidia (b); P. niveus isolated from N. ribisnigri in PDA medium, macromorphology (colony reverse) (c); macromorphology (colony obverse) (d).

biological control of aphids and additional diversity data of entomopathogenic fungal diseases.

\section{References}

ABBOTT, W.S., 1925. A method of computing the effectiveness of an insecticide. Journal of Economic Entomology, vol. 18, no. 2, pp. 65-267. http://dx.doi.org/10.1093/jee/18.2.265a.

ALVES, S.B., 1998. Controle microbiano de insetos. Piracicaba: FEALQ. 1163 p.
ANHALT, F.A., AZEVEDO, J.L., SUGAYAMA, R.L., SPECHT, A. and BARROS, N.M., 2010. Potential of Metarhizium anisopliae (Metsch.) Sorokin (Ascomycetes, hypocreales) in the control of Bonagota salubricola (Meyrick) (Lepidoptera, Tortricidae) and its compatibility with chemical insecticides. Brazilian Journal of Biology = Revista Brasileira de Biologia, vol. 70, no. 4, pp. 931-936. PMid:21180896.

ASMAN, K., 2007. Aphid infestation in field grown lettuce and biological control with entomopathogenic fungi (Deuteromycotina: Hyphomycetes). Biological Agriculture and Horticulture, 
vol. 25 , no. 2 , pp. 153-173. http://dx.doi.org/10.1080/0144876 5.2007.9755043.

BARBER, M.D., MOORES, G.D., TATCHELL, G.M., VICE, W.E. and DENHOLM, I., 1999. Insecticide resistance in the currant-lettuce aphid, Nasonovia ribisnigri (Hemiptera: Aphididae). Bulletin of Entomological Research, vol. 89, no. 1, pp. 17-23. http://dx.doi.org/10.1017/S0007485399000036.

DEDRYVER, C.A., LE-RALEC, A. and FABRE, F., 2010. The conflicting relationships between aphids and men: a review of aphid damage and control strategies. Biologies, vol. 333, no. 6-7, pp. 539-553. http://dx.doi.org/10.1016/j.crvi.2010.03.009. PMid:20541165.

DÍAZ, B.M., LEGARREA, S., MARCOS-GARCÍA, M.Á. and FERERES, A., 2010. The spatio-temporal relationships among aphids, the entomophthoran fungus, Pandora neoaphidis, and aphidophagous hoverflies in outdoor lettuce. Biological Control, vol. 53, no. 3, pp. 304-311. http://dx.doi.org/10.1016/j. biocontrol.2009.12.002.

DORSCHNER, K.W., FENG, M.G. and BAIRD, C.R., 1991. Virulence of an aphid-derived isolate of Beauveria bassiana (Fungi: Hyphomycetes) to the hop aphid, Phorodon humuli (Homoptera: Aphididae). Environmental Entomology, vol. 20, no. 2, pp. 690-693. http://dx.doi.org/10.1093/ee/20.2.690.

FERREIRA, D. F., 2010. SISVAR 2010: sistema de análise de variância. Versão 5.3. Lavras: UFLA.

GERRITS VAN DEN ENDE, A H.G. and HOOG, G.S., 1999. Variability and molecular diagnostics of the neurotropic species Cladophialophora bantiana. Studies in Mycology, vol. 43, no. 1, pp. 151-162.

HOOG, G.S. and GUARRO, J., 2000. Atlas of clinical fungi. 2nd ed. Utrecht: Centraalbureau voor Schimelcultures, Universitat Rovira i Virgili.

HUMBER, R.A., HANSEN, K.S. and WHEELER, M.M., 2011 [viewed 2 May 2014]. ARS collection of entomopathogenic fungal cultures (ARSEF): catalog of species [online]. Ithaca: USDA-ARS Biological IPM Research Unit. Available from: http://www.ars.usda.gov/sp2userfiles/place/19070510/arsefpdfs/ catalog.july2011.pdf

JUKES, T.H. and CANTOR, C.R., 1969. Evolution of protein molecules. In: H.N. MUNRO, ed. Mammalian protein metabolism. New York: Academic Press, pp. 21-132.

LIU, Y.B. and MCCREIGHT, J.D., 2006. Responses of Nasonovia ribisnigri (Homoptera: Aphididae) to susceptible and resistant lettuce. Journal of Economic Entomology, vol. 99, no. 3, pp. 972-978. http://dx.doi.org/10.1093/jee/99.3.972. PMid:16813339.

MARTIN, C., SCHOEN, L., RUFINGIER, C. and PASTEUR, N., 1996. A contribution to the integrated pest management of the aphid Nasonovia ribisnigri in salad crops. IOBC/WPRS Bulletin, vol. 19, pp. 98-101.

PEEL, M.C., FINLAYSON, B.L. and MCMAHON, T.A., 2007. Updated world map of the Köppen-Geiger climate classification. Hydrology and Earth System Sciences, vol. 11, no. 5, pp. $1633-$ 1644. http://dx.doi.org/10.5194/hess-11-1633-2007.

REININK, K. and DIELEMAN, F.L., 1993. Survey of aphid species on lettuce. IOBC/WPRS Bulletin, vol. 16, pp. 56-68.

RUFINGIER, C., SCHOEN, L., MARTIN, C. and PASTEUR, N., 1997. Resistance of Nasonovia ribisnigri (Homoptera: Aphididae) to five insecticides. Journal of Economic Entomology, vol. 90, no. 6, pp. 1445-1449. http://dx.doi.org/10.1093/jee/90.6.1445.

SAITOU, N. and NEI, M., 1987. The neighbor-joining method: a new method for reconstructing phylogenetic trees. Molecular Biology and Evolution, vol. 4, no. 4, pp. 406-425. PMid:3447015.

SAMSON, R.A., HOUBRAKEN, J., VARGA, J. and FRISVAD, J.C., 2009. Polyphasic taxonomy of the heat resistant ascomycete genus Byssochlamys and its Paecilomyces anamorphs. Persoonia, vol. 22, no. 1, pp. 14-27. http://dx.doi.org/10.3767/003158509X418925. PMid:20198134.

SCORSETTI, A.C., JENSEN, A.B., LÓPEZ LASTRA, C. and HUMBER, R.A., 2012. First report of Pandora neoaphidis resting spore formation in vivo in aphid hosts. Fungal Biology, vol. 116, no. 2, pp. 196-203. http://dx.doi.org/10.1016/j.funbio.2011.11.002. PMid:22289765.

SCORSETTI, A.C., MACIÁ, A., STEINKRAUS, D.C. and LÓPEZ-LASTRA, C.C., 2010. Prevalence of Pandora neoaphidis (Zygomycetes: Entomophthorales) infecting Nasonovia ribisnigri (Hemiptera: Aphididae) on lettuce crops in Argentina. Biological Control, vol. 52, no. 1, pp. 46-50. http://dx.doi.org/10.1016/j. biocontrol.2009.09.005.

SKINNER, M., GOULI, S., FRANK, C.E., PARKER, B.L. and KIM, J.S.U., 2012. Management of Frankliniella occidentalis (Thysanoptera: Thripidae) with granular formulations of entomopathogenic fungi. Biological Control, vol. 63, no. 3, pp. 246-252. http://dx.doi.org/10.1016/j.biocontrol.2012.08.004.

STADEN, R., 1996. The Staden sequence analysis package. Molecular Biotechnology, vol. 5, no. 3, pp. 233-241. http://dx.doi. org/10.1007/BF02900361. PMid:8837029.

STEINKRAUS, D.C., 2006. Factors affecting transmission of fungal pathogens of aphids. Journal of Invertebrate Pathology, vol. 92, no. 3, pp. 125-131. http://dx.doi.org/10.1016/j.jip.2006.03.009. PMid:16780867.

SUN, B. and LIU, X., 2008. Occurrence and diversity of insect-associated fungi in natural soils in China. Applied Soil Ecology, vol. 39, no. 1, pp. 100-108. http://dx.doi.org/10.1016/j. apsoil.2007.12.001.

TAMURA, K., DUDLEY, J., NEI, M. and KUMAR, S., 2007. MEGA4: Molecular Evolutionary Genetics Analysis (MEGA) software version 4.0. Molecular Biology and Evolution, vol. 24, no. 8, pp. 1596-1599. http://dx.doi.org/10.1093/molbev/msm092. PMid: 17488738 .

WHITE JUNIOR, J.F., MORROW, A.C. and MORGAN-JONES, G., 1990. Endophyte-host associations in forage grasses. XII. A fungal endophyte of Trichachne insularis belonging to Psedocercosporella. Mycology, vol. 82, no. 2, pp. 218-226. http:// dx.doi.org/10.2307/3759850.

ZAKI, F.N., 1998. Efficiency of the entomopathogenic fungus, Beauveria bassiana (Bals), against Aphis crassivora Koch and Bemisia tabaci, Gennandius. Journal of Applied Entomology, vol. 122, no. 1-5, pp. 397-399. http://dx.doi.org/10.1111/j.1439-0418.1998. tb01518.x.

ZIMMERMANN, G., 2008. The entomopathogenic fungi Isaria farinosa (formerly Paecilomyces farinosus) and the Isaria fumosorosea species complex (formerly Paecilomyces fumosoroseus): biology, ecology and use in biological control. Biocontrol Science and Technology, vol. 18, no. 9, pp. 865-901. http://dx.doi.org/10.1080/09583150802471812. 